\title{
Significant Colonization of Inoculated Endophytic Fungus, Hendersonia toruloidea GanoEF1 within Oil Palm Root at PASFA Bukit Kerisek (Pahang) Using GanoEF biofertilizer
}

\author{
Shih Hao Tony Peng ${ }^{*}$, Chee Kong Yap ${ }^{2}$, Roslan Arshad ${ }^{1}$, Ee Wen Chai ${ }^{1}$, Helmy Hamzah ${ }^{1}$, Abu \\ Seman Idris ${ }^{3}$, Nur Rashyeda Ramli ${ }^{3}$ \\ ${ }^{1}$ All Cosmos Bio-Tech Holding Corporation, PLO650, Jalan Keluli, Pasir Gudang Industrial Estate, \\ 81700 Pasir Gudang, Johor, Malaysia \\ ${ }^{2}$ Department of Biology, Faculty of Science, Universiti Putra Malaysia, 43400 UPM, Serdang, Selangor, \\ Malaysia \\ ${ }^{3}$ Malaysian Palm Oil Board, 6 Persiaran Institusi, Bandar Baru Bangi, 43000 Kajang, Selangor, \\ Malaysia
}

Received Date: June 18, 2020; Accepted Date: June 24, 2020; Published Date: July 03, 2020

"Corresponding author: Shih Hao Tony Peng, All Cosmos Bio-Tech Holding Corporation, PLO650, Jalan Keluli, Pasir Gudang Industrial Estate, 81700 Pasir Gudang, Johor, Malaysia. Email: tonypeng@allcosmos.com

\section{Abstract}

The roots of oil palm (Elaeis guineensis Jacq.) previously treated with GanoEF biofertilizer product (500g/planting hole) were sampled from oil palm plantation at PASFA's Bukit Kerisek (Pahang, Peninsular Malaysia). These root samples were identified for the colonization of inoculated endophytic fungus, Hendersonia toruloidea GanoEF1 within the oil palm roots. Results showed that Hendersonia GanoEF1 colonization in primary and feeder roots were $19.3-21.6 \%$, and $37.5-42.5 \%$, respectively. Therefore, the use of Gano EF biofertilizer was proven successfully colonized in both primary and feeder roots of oil palm. This positive outcome clearly indicated the infection of Ganoderma fungus, the causal pathogen of basal stem rot disease can be controlled in oil palm plantation.

Keywords: Basal Stem Rot; Hendersonia; Oil Palm

\section{Introduction}

The oil palm in Malaysia, the commercial crop oil palm (Elaeis guineensis Jacq.) has been challenged with Ganoderma fungus, the causal pathogen of basal stem rot (BSR). This has been a serious pathogenic threat to the production of oil palm, which consequently results in unyielding economic losses [1]. In 2016-2017, the incidence of BSR in Malaysia was 7.4\%, with 221000 ha of affected areas [2]. Therefore, a biological way to control the pathogenic disease is much needed to sustain the oil palm industry in Malaysia.

Environmental problems caused by chemical fertilizers in the oil palm plantation have accelerated research on management methods in line with environmentally friendly fertilizers, such as the use of biofertilizers [3, 4]. Thus, the development of GanoEF biofertilizer containing endophytic fungus, Hendersonia toruloidea GanoEF1 incorporated into inorganic and organic fertilizers was successfully produced in collaboration betweenMalaysian Palm Oil Board (MPOB) and All Cosmos Industries Sdn. Bhd., Pasir Gudang, Johor [5]. The endophytic fungus, $H$. toruloidea GanoEF1has been found to be strongly antagonistic against Ganoderma boninense in various laboratory and nursery studies [6-9]. The benefits of GanoEF biofertilizer including: 1) effectively controlling Ganoderma disease, 2) environmental-friendly, 3) easy storage, and 4), easy application in the nursery and field conditions [5].

From scientific research point of view, the use of a proposed product should be tested for their efficacy in order to prove 
their effectiveness in the field. Since the evidence of using the GanoEF product in the roots of oil palm at The Pahang Farmers' Organisation (PASFA) Bukit Kerisek, Pahang, Malaysia is lacking in the literature, therefore, the objective of this study was to identify the colonization of inoculated $H$. toruloidea GanoEF1 using the above GanoEF product within the root of oil palm sampled from oil palm plantation at Bukit Kerisek, Pahang, Peninsular Malaysia.

\section{Materials and Methods}

Root sample from a treated palm was obtained from oil palm plantation at PASFA's Bukit Kerisek, Pahang, and Peninsular Malaysia. The oil palm chosen in the present study was previously treated with GanoEF biofertilizer product (500g/planting hole). The sampling of the oil palm roots was conducted on the 8th August 2016. The sampling was conducted 8 months after the application of the GanoEF biofertilizer product.

The entire root system was washed with tap water to remove the adhering soil and divided into two parts (Sample 1, Sample 2). The roots were subsequently surface sterilized with chlorox $(20 \% \mathrm{v} / \mathrm{v})$ and ethanol $(70 \% \mathrm{v} / \mathrm{v})$ before washing with sterile water. The surface sterilized roots were then divided into primary and feeder root sections. A total of 60 primary root sections and 40 feeder root sections from both palms were placed on selective agar media (Rose Bengal Chloramphenicol Agar) and incubated at $28^{\circ} \mathrm{C}$ for $1-2$ weeks for $H$. toruloidea GanoEF1 determination. The percentage colonization of $H$. toruloidea GanoEF1 was calculated by using the following equation (adapted from Campbell and Madden, 1990) [10]:

Root colonization percentage per sample $=$ (No. of root sections with target fungus) / (Total No. of sections)

\section{Results and discussion}

Percentages of root colonization of Hendersonia GanoEF1 per sample are shown in (Table 1). Sample 1 showed 19.30\% of $H$. toruloidea colonization in the primary roots and $42.50 \%$ colonization in the feeder roots. Root sections from Sample 2 showed $21.60 \%$ colonization in the primary roots and $37.50 \%$ colonization in the feeder roots. The present results are also well supported by Munthe and Dahang (2018) [11] who reported $24-28 \%$ of root colonization of $H$. toruloidea GanoEF1, based on the roots of oil palm collected in 2017 from two locations in Riau Province, Indonesia.

Table 1: Percentages of oil palm root colonization of Hendersonia toruloidea GanoEF1.

\begin{tabular}{|c|c|c|c|}
\hline Sample & $\begin{array}{c}\text { No. of root } \\
\text { sections }\end{array}$ & $\begin{array}{c}\text { No. of root sections colonized by } \\
\text { Hendersonia toruloidea }\end{array}$ & $\begin{array}{c}\text { Hendersonia root } \\
\text { colonization }(\%)\end{array}$ \\
\hline 1 (Primary root) & 60 & 11 & 19.3 \\
\hline 1 (Feeder root) & 40 & 17 & 42.5 \\
\hline 2 (Primary root) & 60 & 13 & 21.6 \\
\hline 2 (Feeder root) & 40 & 15 & 37.5 \\
\hline
\end{tabular}

The presence of endophytic fungus, $H$. toruloidea GanoEF1 in both primary and feeder roots of oil palm has proven that this fungus was successfully colonized (Figure 1). Colonization will be increased proportionately with time (subject to favourable condition) and positively will control the infection of Ganoderma disease in oil palm plantation. However, it is highly recommended to apply GanoEF biofertilizer $(2 \mathrm{~kg} / \mathrm{palm})$ for another three subsequent years to enhance more colonization of Hendersonia sp. This is an important management strategy to reduce and protect the oil palm from being infected by BSR disease.

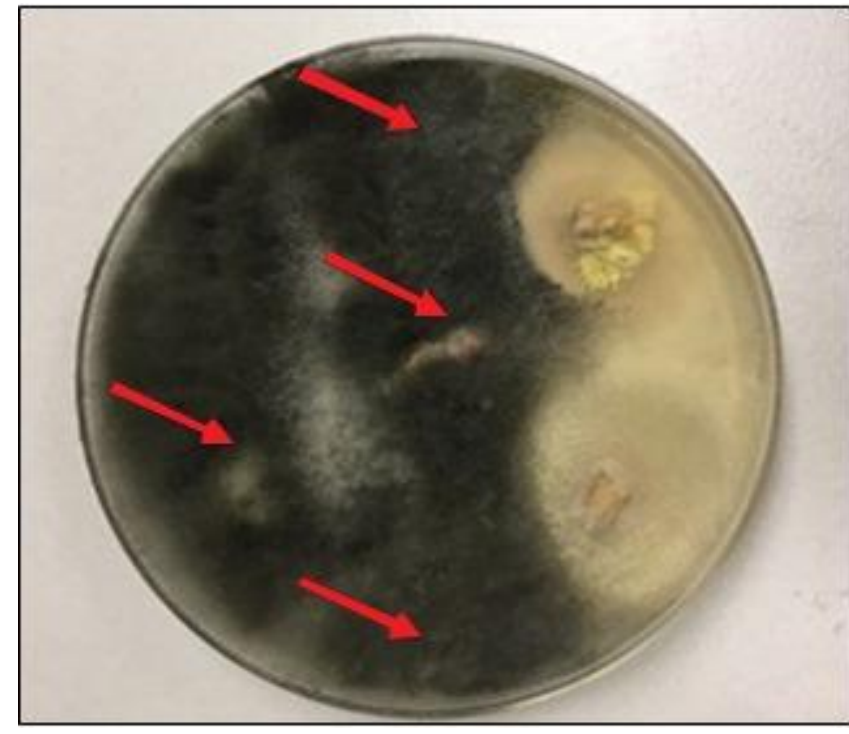

Figure 1: Hendersonia toruloidea GanoEF1 on PDA plate after seven days of incubation (red arrows). 
Several studies have been reported to the $H$. toruloidea GanoEF can reduce the Ganoderma infection in the oil palm plantations. Earlier, Idris et al. (2012) [5] used the biofertilizer GanoEF contained $H$. toruloidea GanoEF and it can significantly reduce the Ganoderma incidence up to $69.5 \%$. Based on screening using liquid culture and dual culture bioassays, Ramli et al. (2018) [7] reported that Hendersonia sp. isolate GanoEF1 had been proven effective in the control of $G$. boninense growths in both bioassays. It was concluded that $H$. toruloidea isolate GanoEF1 has played a significant role as in controlling BSR disease of oil palm. Kamarudin et al. (2017) [12] reported the enrichment of thiamine biosynthesis by colonization of $H$. toruloidea in oil palm roots. Undoubtedly, GanoEF biofertilizer is one of biotechnological fertilizers product as well as biofungicides, a combination of endophytic fungus, Hendersonia GanoEF1 that are advantageous in terms of promoting soil fertility and prevention of Ganoderma incidence in oil palm plantation [5].

\section{Conclusions}

In conclusion, the present study exhibited that $H$. toruloidea colonization in primary and feeder roots were 19.3$21.6 \%$, and $37.5-42.5 \%$, respectively. Therefore, the use of GanoEF biofertilizer product $(500 \mathrm{~g} /$ planting hole) has proved that the respective fungus was successfully colonized in both primary and feeder roots of oil palm. This positive outcome clearly indicates the infection of BSR disease can be controlled in oil palm plantation. Successful colonization by $H$. toruloidea GanoEF1 into oil palm root will reduce the Ganoderma infection. Besides, regular survey and monitoring of BSR incidence are highly recommended at the oil palm plantation so that the Ganoderma disease can be controlled effectively by using GanoEF biofertilizer.

Funding: This research received research grant from All Cosmos Industries SdnBhd, Johor, Malaysia.

Competing Interests: The authors have declared that no competing interests exist.

\section{References}

1. Kushairi A, Soh KL, Azaman I, Elina H, Meilina-Ong A, et al. (2018) Oil palm economic performance in Malaysia and R \& D progress in 2017. Journal of Oil Palm Research 30: 163-195.

2. Idris A S, MohdShukri I, Izzuddin MA, Norman K, Khairuman H, et al. (2019) Survey on status of Ganoderma disease of oil palm estates and smallholders in Malaysia.
Presented atthe MPOB International Palm Oil Congress and Exhibition (PIPOC) 2019, 19-21 November 2019, Kuala Lumpur Convention Centre (KLCC), Kuala Lumpur, Malaysia.

3. Castillo C, Huenchuleo MJ, Michaud A, Solano J (2016) Mycorrhizae in a potato crop added Twin-N biofertilizer in an Andisol of the Araucanía Region.Idesia 34: 39-45.

4. Celador-Lera L, Jiménez-Gómez A, Menéndez E, Rivas R (2018) Biofertilizers based on bacterial endophytes isolated from cereals: Potential solution to enhance these crops. Role of Rhizospheric Microbes in Soil. Stress Management and Agricultural Sustainability 1: 175-203.

5. Idris AS, Nurrashyeda R, Maizatul SM, Madihah AZ, Tarmizi AM, et al. (2012) BiofertiliserHendersonia GanoEF as biological control of Ganoderma in oil palm. Malaysian Palm Oil Board (MPOB) Information Series. No. 508, 4pp.

6. Ramli NR, Idris AS, Madihah AZ, Ramli M, Kushairi A (2011) Hendersonia GanoEF1 granules for the control of Ganoderma boninense in oil palm. Malaysian Palm Oil Board (MPOB) Information Series. No. 556, 4pp.

7. Ramli NR, Idris AS, Madihah AZ, Maizatul-Suriza M, Noor Haida S (2018) Biocontrol of Basal Stem Rot (BSR) Disease of Oil Palm Using Endophytic Fungus, Hendersonia sp. International Journal of Pure and Applied Mathematics. 118: $1-22$.

8. Idris AS, Noor Haida S, Nurrashyeda R (2010) GanoEF1A fungal biocontrol agent for Ganoderma in oil palm. Malaysian Palm Oil Board (MPOB) Information Series. No. 501, 444pp.

9. Azman MD, Malek RA, Othman NZ, Peng TSH, Idris A, et al. (2012) Semi-industrial scale production of biocontrol fungus: Hendersonia sp., a potential agent against Ganoderma oil palm disease. Conference paper presented at 2012 AIChE Annual Meeting; Pittsburgh, PA; United States; 28 October-2 November 2012; Code 94591.

10. Campbell CL, Madden LV (1990) Introduction to plant disease epidemiology. New York: John Wiley and Sons.

11. Munthe KPSM, Dahang D (2018) Hosting of Hendersonia against Ganoderma (Ganoderma boniense) disease in oil palm (Elaeis guineensis Jacq). International Journal of Multidisciplinary Research and Development 5: 46-50.

12. Kamarudin AN, Lai KS, Lamasudin DU, Idris AS, BaliaYusof ZN (2017) Enhancement of thiamine biosynthesis in oil palm seedlings by colonization of endophytic fungus Hendersonia toruloidea. Frontiers in Plant Science 8: 1799.

Citation: Peng SHT, Yap CK, Arshad R, Chai EW, Hamzah H, Idris S, Ramli NR (2020) Significant colonization of inoculated endophytic fungus, Hendersonia toruloidea GanoEF1 within oil palm root at PASFA Bukit Kerisek (Pahang) using GanoEF biofertilizer. Adv Agri Horti and Ento: AAHE-125. 